\title{
Vaccine Coverage Rates Among 12-23 Month Old Children Living in Four Selected Provinces of Turkey: Results of a Lot Quality Survey
}

\author{
Türkiye'de Seçilmiş Dört İl Merkezinde \\ Yaşayan 12-23 Ay Arasındaki \\ Çocuklarda Aşılanma Oranları: \\ Lot Kalite Araştırması Sonuçları
}

\author{
Sarp ÜNER, MD, Assoc.Prof., ${ }^{a}$ \\ Pervin ÖZELÇl, MD, Msc, ${ }^{b}$ \\ Seracettin ÇOM, MD, ${ }^{b}$ \\ Mustafa KOSDAK, MD, ${ }^{\circ}$ \\ Salih MOLLAHALILOĞLU, MD, ${ }^{c}$ \\ Yasin ERKOÇ, MD
}

aDepartment of Public Health,

Hacettepe University

Faculty of Medicine,

${ }^{b}$ General Directorate of

Primary Health Care, Ministry of Health,

'School of Public Health,

Ministry of Health,

dDeputy Undersecretary,

Ministry of Health, Ankara

Geliş Tarihi/Received: 21.06.2011

Kabul Tarihi/Accepted: 12.01.2012

Yazışma Adresi/Correspondence:

Sarp ÜNER, MD, Assoc.Prof.

Hacettepe University

Faculty of Medicine,

Department of Public Health, Ankara,

TÜRKIYE/TURKEY

sarpuner@hacettepe.edu.tr

\begin{abstract}
Objective: The aim of the study is to evaluate the coverage rates for routine childhood vaccines at the provincial-level and to identify the districts with "unacceptably low" coverage rates. Material and Methods: A Lot Quality Technique -based cross-sectional study was conducted in four selected provinces, on a representative sample of residents aged 12-23 months in order to evaluate coverage for routine childhood vaccines [Bacille Calmette-Guérin (BCG), diphtheria, tetanus, pertussis, polio \& Haemophilus influenzae type b (DTaPHibIPV3), oral polio vaccine (OPV), Hepatitis B3 and measles, mumps \& rubella (MMR)], to identify the districts with coverage rates below $75 \%$, and to investigate reasons for non-vaccination. Results: A total of 1640 children were included in the survey. Based on self-reports, the percentage of fully immunized children ranged between $88.6 \%$ and $98.1 \%$ in the four provinces. The percentage of timely vaccinations varied from 71.5 to 78.4 , according to the type of the vaccine and overall coverage rates were below $75 \%$ in four lots. Potential associations between children's "fully and timely vaccination" status and some socio-demographic characteristics were examined with logistic regression modeling. The results have shown that the estimated risk of improper/inadequate vaccination is affected positively by having an employed mother, a primary school graduate or less educated mother and mother's age but is negatively affected by the child's age. Conclusion: This study identified vaccine coverage for ten routine vaccines that should be completed before the age of 24 months and the areas that need a special attention in vaccination services.
\end{abstract}

Key Words: Vaccination; lot quality assurance sampling; immunization schedule; child

ÖZET Amaç: Çalışmanın amacı il düzeyinde rutin çocukluk çağı aşılarının kapsayıcılı̆̆ını değerlendirmek ve kabul edilemeyecek düzeyde düşük aşı kapsayıcılığının olduğu bölgeleri belirlemektir. Gereç ve Yöntemler: Oniki-23 ay arasındaki çocuklarda rutin çocukluk çağı aşılarının [Bacille Calmette-Guérin (BCG), difteri, tetanoz, boğmaca, polio \& Haemophilus influenzae tip b(DTaPHibIPV3), oral polio aşısı (OPA), Hepatit B3 and kızamık, kabakulak ve kızamıkçık (KKK] yapılma oranlarını değerlendirmek, aşılama oranları \%75'in altındaki bölgeleri belirlemek ve aşılamamanın nedenlerini araştırmak için Lot Kalite Tekniğine dayalı kesitsel çalışma seçilmiş dört ilde gerçekleştirildi. Bulgular: Toplam 1640 çocuk çalışmaya alınmıştır. Katılımcılardan alınan bilgilere göre, dört ilde tam olarak aşılanmış çocukların oranları \%88,6 ile \%98,1 arasında değişmekteydi. Zamanında aşılama yüzdesi aşının tipine göre $\% 71,5$ ile $\% 78,4$ arasında değişmekte olup, genel aşılanma kapsayıcılı̆̆ dört lotta \%75'in altında olarak saptanmıştır. Çocukların tam ve zamanında aşılanma durumları ile bazı sosyodemografik özellikler arasındaki potansiyel ilişkiler lojistik regresyon modeli ile incelenmiştir. Sonuçlar, uygunsuz/yetersiz aşılanma için tahmin edilen riskin annenin çalışması, ilkokul mezunu veya daha düşük eğitimli olması ve annenin yaşından olumlu olarak etkilenmekte olduğunu fakat çocuğun yaşından olumsuz olarak etkilenmekte olduğunu göstermiştir. Sonuç: Bu çalışma 24 aydan önce tamamlanması gereken on rutin aşının kapsayıcılığını ve aşılama hizmetlerinde özel dikkat gerektiren bölgeleri ortaya koymuştur.

Anahtar Kelimeler: Aşılama; öbek kalite güvence örneklemesi; aşı program; çocuk 
$\mathrm{V}$ -accine preventable diseases in childhood still constitute an important public health problem. As vaccine-preventable diseases still pose significant threats, strengthening immunization programs remains vital. ${ }^{1}$ Vaccination, regarded as one of the greatest achievements in medicine and one of the most cost-effective health care practices, is a public health practice of major significance in preventing diseases. Immunization is also one of the human and child rights, which was clearly stated in Article 25 of the Universal Declaration of Human Rights and in Article 24 of the Convention on the Rights of the Child.

Turkey is a country with 72 million inhabitants and about $75 \%$ of the population lives in urban areas. Administratively, the country is divided into 81 provinces and more than 900 districts. Approximately 1.3 million babies are born and vaccinated against 11 diseases annually. ${ }^{2}$

Several factors may interfere with vaccination rates such as awareness of the parents on the vital importance of vaccination in childhood; availability, accessibility and acceptability of vaccination services; familial, social, cultural and economic factors. Despite well-defined national vaccination programs and efforts to increase vaccine coverage rates, desired levels may not be reached or even fall below "acceptable" levels in some regions or districts. Data on performance at the local level is vital to enhance overall vaccination coverage. Routine surveillance programs are crucial for baseline estimations and proper follow-up of vaccination services, yet, not always complete and reliable: resources and manpower are usually limited, data are available only for those "who seek medical advice/service", and/or data collection forms may/may not include the information required. Periodic household surveys may be beneficiary in reaching even those least likely to seek medical help and who cannot have access to the services. Several survey techniques can be used for determining vaccination coverage rates at a given setting, where each technique has certain advantages and disadvantages, given the resources. ${ }^{3-6}$

The Lot Quality Technique (LQT) has long been used for evaluating vaccine coverage rates.
This technique can easily be conducted by local staff/trained interviewers and is particularly efficient when there's an overall high coverage of the population, while, sub-units of the population are heterogeneous in coverage rates; and, is advantageous where coverage rates of individual sub-units of the population need to be evaluated. . $7,8^{2}$

According to Robertson and et al., interest in applying lot quality assurance sampling (LQAS) to health assessments has been growing since the mid-1980s. They showed, in their review of literature study, that 266 of the 805 surveys were on immunization coverage in the period 1984-2004. The number of studies on immunization coverage carried out with LQT increased to 195 between the years 2000 to 2004, while it was only 10 between the years 1984-1989. These studies were carried out in 35 different countries and 210 of them (78.9\%) were in rural areas. One hundred twelve surveys assessed immunization coverage in children, mostly between 12-23 months of age. ${ }^{9}$

In this study, a population-based survey was planned to evaluate coverage rates for routine childhood vaccines on the provincial-level; to identify the districts with "unacceptably low" vaccination coverage rates (if any); and, to investigate reasons for non-vaccination.

\section{MATERIAL AND METHODS}

A cross-sectional epidemiologic study was conducted on a representative sample of children aged 12-23 months (henceforth referred to as "children") to establish valid and reliable estimates for evaluating effectiveness of the routine vaccination services provided in the region and to ultimately provide scientific evidence for tailoring future interventions in the region to maximize vaccination rates among children. The survey was conducted and completed between September 27 and November 02, 2010.

During the study, Turkey was in a transition period on the provision of health services. The number of provinces determined depending on the availability of resources and the universe of the research consists of four provinces in which two of 
them have family medicine implementation. In some regions (including Elazı̆ $\breve{g}$ and Samsun provinces) primary health care services were provided by family physicians, whereas health centers were responsible for providing this service in other parts of the country (including Balıkesir and Giresun provinces). Selecting two family medicine implementation provinces primarily, and then establishing other provinces according to this two provinces would be more appropriate in the determination of the provinces. Starting date of family medicine implementation, the fully immunized percent according to the target population and lot number have been regarded as selection criteria for the first two provinces.

Data of the study was collected via household surveys, based on parents' (or care-givers ') self-reports and children's vaccination cards, whenever available.

In the study, coverage rates were calculated for each province as a whole, and districts with coverage rates below $75 \%$ were identified as the units with "unacceptably low" coverage rates. Ten vaccines were included in the study and a child was considered as "fully-immunized" if s/he was vaccinated for Bacille Calmette-Guérin (BCG), three doses of diphtheria, tetanus, pertussis, polio \& Haemophilus influenzae type b (DTaPHibIPV), Hepatitis B, and one dose of (measles, mumps \& rubella (MMR). ${ }^{10}$ The quality of services was also evaluated based on two criteria: presence of a vaccination card and "timeliness" of vaccinations.

In the study, the LQT was used to select children and to perform district-specific evaluations. Each district of the selected provinces was desig- nated as a "lot", providing data for calculation of coverage rates and determining the "quality" of services.

The LQT was originally derived from production-line industry to categorize the quality of batchs of a product as either permissible or unsatisfactory based on the production of defective units in each found by inspecting a sample of units ("lots"). In evaluating vaccination services in a selected area, the population is divided into individual (administrative or service) units; where a sufficient number of subjects are randomly chosen from each unit; and, vaccination status of those selected children are evaluated. The total sample size in the study was determined based on the total population aged 12-23 months; acceptable levels of vaccination coverage and the desired level of confidence and level of accuracy in reaching a valid estimate. In the study, the "acceptable range" was set from $75 \%$ to $95 \%$ (the national target). ${ }^{10}$ Any lot with a coverage rate of $<75 \%$ was identified as "having unacceptably low" coverage, and thus, required urgent attention. The coverage rate for each vaccine was calculated for the total population with a confidence level of $95 \pm 5 \%$. $^{7}$ Some characteristics of the provinces in the study are shown in Table 1.

The required total sample size was calculated as minimum 384 people for each province. ${ }^{7}$ Lots are determined as districts and considering number of child for each lot, it is thought that lot number in a province ought to be between 10 and 20. Number of lots, lot sample sizes, total sample sizes and decision values for each province are presented in Table 1 . The decision values were identified using Sample LQ software package.

\begin{tabular}{|c|c|c|c|c|c|c|c|c|}
\hline \multirow[b]{3}{*}{ Province } & & & \multirow{3}{*}{$\begin{array}{l}\text { Number of } \\
\text { Lots }\end{array}$} & \multirow{3}{*}{$\begin{array}{l}\text { Lot sample } \\
\text { size }\end{array}$} & \multirow{3}{*}{$\begin{array}{l}\text { Minimum Total sample } \\
\text { size required }\end{array}$} & \multicolumn{2}{|c|}{ Number of children } & \multirow{3}{*}{$\begin{array}{c}\text { Decision } \\
\text { value }\end{array}$} \\
\hline & \multicolumn{2}{|c|}{ Population } & & & & & Included in & \\
\hline & Total & $12-23$ months old & & & & Reached & the analysis & \\
\hline Balıkesir & 1079724 & 11987 & 19 & 21 & 399 & 403 & 403 & 2 \\
\hline Elazığ & 548707 & 8673 & 11 & 35 & 385 & 416 & 410 & 4 \\
\hline Giresun & 386399 & 4683 & 16 & 24 & 384 & 413 & 407 & 3 \\
\hline Samsun & 1233677 & 17423 & 17 & 23 & 391 & 425 & 420 & 2 \\
\hline
\end{tabular}


In the study, data were based on self-reports of the children's caregiver (mother, whenever possible). A questionnaire, which was based on the data collection tool of the study conducted by Cakir et al., was used to conduct face-to-face interviews at household settings. ${ }^{11}$ The 3 -page questionnaire was completed in about 15 minutes and included questions on sociodemographics, vaccine-related characteristics of children, family characteristics, and reasons for non-vaccination (if applicable).

The children were considered as immunized or not, based on their immunization cards. For those without an immunization card, self-report of the mother or any other responsible and reliable person in the family with respect to the immunization status of the child was considered.

SPSS version 15 statistical software package (Chicago, IL) was used for data analysis, which included frequency and percent distributions; calculation of coverage rates for individual vaccines for children in selected provinces; and identification of lots with coverage rates below 75\%. Based on LQT, questionnaires were filled out for an equal number of children from each lot, regardless of the population of children aged 12-23 months. For this reason, analysis of the level of vaccination coverage for the entire province was conducted using appropiate sampling weights. Multivariate logistic regression modeling was used to identify significant predictors of "fully and timely vaccination" in advanced analysis section, where all potential confounders identified from stratified analiysis of the data and/or literarture search where included in the baseline model.

Written permission for the study was obtained from the Ministry of Health of Turkey. The objectives of the survey were explained to potential respondents, who were free to refuse participation before or at any time during the survey. Oral informed consents were obtained from parents of selected children before the interviews.

\section{RESULTS}

A total of 1640 children were included in the study. Table 2 presents distiribution of some selected socio-demographic characteristics of the parents and children in the study by provinces.
Sixty seven percent of the children reached vaccination services in less than 10 minutes, and $96.7 \%$ of the children were taken to a health center/family physician for immunization in Balıkesir, while these percentages were 52.0 and 99.6 in Elazığ, 56.0 and 97.2 in Giresun, and 51.0 and 100.0 in Samsun, respectively.

In total, the percentages of children, who had a vaccination card ranged from $82.5 \%$ to $91.6 \%$, while only $0.6-3.0 \%$ of the children were reported not to have a vaccination card.

The percentage of timely vaccinations varied from 71.5 to 78.4 , according to the type of the vaccine in Balıkesir province. However, the mean age for immunization was calculated as 69 days for BCG vaccine, 193 days for DTaPHibIPV3 vaccine, 194 days for OPV, 195 days for Hepatitis B3 vaccine, and 373 days for MMR vaccine (Table 3).

The percentage of timely vaccinations varied from 60.2 to 62.8 according to the type of the vaccine in Elazı $\mathrm{g}$ province. However, the mean age for immunization was calculated as 79 days for BCG vaccine, 202 days for DTaPHibIPV3 vaccine, 198 for OPV, 200 days for Hepatitis B3 vaccine, and 375 days for MMR vaccine (Table 3).

The percentage of timely vaccinations varied from 47.4 to 65.6 , according to the type of the vaccine in Giresun province. However, the mean age for immunization was calculated as 74 days for BCG vaccine, 203 days for DTaPHibIPV3 vaccine, 202 days for OPV, 206 days for Hepatitis B3 vaccine, and 378 days for MMR vaccine (Table 3).

Lastly, the percentage of timely vaccinations varied from 73.1 to 76.2 according to the type of the vaccine in Samsun province. However, the mean age for immunization was calculated as 70 days for BCG vaccine, 197 days for DTaPHibIPV3 vaccine, 201 days for OPV, 197 days for Hepatitis B3 vaccine, and 375 days for MMR vaccine (Table 3).

The percentage of fully immunized children was calculated as $98.1 \%$ in Balıkesir, $97.7 \%$ in Elazı $\breve{g}$, 95.2\% in Giresun, and 88.6\% in Samsun. In the study, $6.9 \%$ of the children were found to have one or more vaccine missing. Percentage of children without any vaccination was $2.3 \%$. Timely 


\begin{tabular}{|c|c|c|c|c|c|}
\hline \multirow[b]{2}{*}{ Variables } & & \multirow[b]{2}{*}{ Balıkesir } & \multicolumn{2}{|c|}{ Provinces $(\%)^{1}$} & \multirow[b]{2}{*}{ Samsun } \\
\hline & & & Elazığ & Giresun & \\
\hline \multirow[t]{3}{*}{ Relation of the participant to the children* } & Mother & 90.3 & 85.4 & 88.7 & 88.5 \\
\hline & Father & 3.3 & 7.6 & 7.0 & 3.2 \\
\hline & Other & 6.4 & 7.0 & 4.3 & 8.3 \\
\hline \multirow[t]{2}{*}{ Age of mother (year) } & mean $\pm S D$ & $28.6 \pm 5.5$ & $29.1 \pm 5.3$ & $29.3 \pm 5.5$ & $27.8 \pm 5.3$ \\
\hline & median (min-max) & $28(17-44)$ & $29(15-52)$ & $29(18-48)$ & $27(15-43)$ \\
\hline \multirow[t]{5}{*}{ Education level of mother* } & Illiterate/Literate & 3.7 & 19.1 & 5.9 & 8.4 \\
\hline & Primary school & 45.4 & 46.3 & 52.1 & 56.1 \\
\hline & Secondary school & 10.7 & 7.2 & 12.5 & 16.7 \\
\hline & High school & 23.3 & 19.2 & 24.3 & 11.8 \\
\hline & University & 16.8 & 8.2 & 5.3 & 7.0 \\
\hline \multirow[t]{2}{*}{ Employment status of mother* } & Employed & 13.6 & 11.5 & 8.0 & 9.2 \\
\hline & Unemployed & 86.4 & $87.9^{*}$ & 92.0 & $90.7^{*}$ \\
\hline \multirow[t]{2}{*}{ Age of father } & mean $\pm S D$ & $32.8 \pm 6.9$ & $33.1 \pm 5.8$ & $34.1 \pm 5.7$ & $31.8 \pm 6.1$ \\
\hline & median (min-max) & $32(19-61)$ & $33(19-58)$ & $34(22-56)$ & $31(16-55)$ \\
\hline \multirow[t]{5}{*}{ Education level of father* } & Illiterate/Literate & 1.5 & 3.2 & 0.9 & 0.2 \\
\hline & Primary school & 33.8 & 31.9 & 39.2 & 54.3 \\
\hline & Secondary school & 19.9 & 12.4 & 19.2 & 18.9 \\
\hline & High school & 23.5 & 37.4 & 28.6 & 16.2 \\
\hline & University & 21.3 & $14.8^{*}$ & 12.1 & 10.1 \\
\hline \multirow[t]{2}{*}{ Employment status of father } & Employed & 89.3 & 86.0 & 87.1 & 91.4 \\
\hline & Unemployed & $10.4^{*}$ & $13.6^{*}$ & $12.7^{*}$ & $8.0^{*}$ \\
\hline \multirow[t]{2}{*}{ Sex of children } & Male & 49.7 & 49.0 & 52.7 & 45.8 \\
\hline & Female & 50.3 & 51.0 & 47.3 & 54.2 \\
\hline \multirow[t]{2}{*}{ Age of children (days) } & mean $\pm S D$ & $532.6 \pm 99.7$ & $515.7 \pm 99.1$ & $532.1 \pm 101.8$ & $540.4 \pm 104.0$ \\
\hline & median (min-max) & $531(366-729)$ & $522(365-727$ & $522(366-729)$ & $543(365-725)$ \\
\hline \multirow[t]{4}{*}{ The number of siblings } & No sibling & 47.6 & 35.3 & 24.1 & 32.2 \\
\hline & 1 & 36.8 & 38.0 & 42.1 & 40.4 \\
\hline & 2 & 13.1 & 17.1 & 22.9 & 17.6 \\
\hline & 3 or more & 2.5 & 9.6 & 18.9 & 9.8 \\
\hline \multirow[t]{3}{*}{ Household size } & 3 & 36.5 & 24.4 & 17.0 & 16.8 \\
\hline & 4 & 37.1 & 29.3 & 33.4 & 24.2 \\
\hline & 5 or more & 26.4 & 46.3 & 49.6 & 59.0 \\
\hline
\end{tabular}

${ }^{1}$ weighted percents are provided

* Percent of missing observations are not presented

vaccination among children ranged from $76.5 \%$ to $69.6 \%$, according to the type of vaccine. Reasons for incomplete vaccination were stated as; lack of knowledge on the place of vaccination, distance travelled to the health center, family problems, not taking the child to the health center for vaccination because of an illness of the child, refusal of vaccination by health care providers because of an illness of the child, waiting at home for vaccination, and lack of available vaccine.
The coverage rate of vaccines ranged from 98.7 to $99.4 \%$ in Balıkesir, 98.2 to $99.9 \%$ in Elazı $\breve{g}$, 97.0 to $99.5 \%$ in Giresun, and 92.5 to $99.4 \%$ in Samsun. There were more than $2 / 21$ unvaccinated children (DTaPHibIPV3, Hepatitis B3, MMR) in one lot of Balıkesir, more than 3/24 unvaccinated children (BCG, DTaPHibIPV3, OPV, Hepatitis B3, MMR) in one lot of Giresun, and more than 2/23 unvaccinated children (BCG, OPV, Hepatitis B3, MMR) in two lots of Samsun, meaning the quality of the vac- 


\begin{tabular}{|lcccccccc|}
\hline \multicolumn{4}{r}{ TABLE 3: The distribution of the vaccine application age according to the vaccine card of } \\
children aged 12-23 months (2010).
\end{tabular}

${ }^{1}$ The vaccine schedule which is used in family medicine practice by the Ministry of Health was taken into account in calculation of the timely vaccination. ${ }^{12}$ According to that schedule, 60-89 days for BCG vaccine, 180-209 days for DTaPHibIPV3, OPV and Hepatitis B3 vaccine and 365-394 days for MMR vaccine were regarded as "timely".

${ }^{2}$ Vaccine application age (Mean \pm SD in days).

BCG: Bacille Calmette-Guérin; DTaPHibIPV3: Diphtheria, tetanus, pertussis, polio \& Haemophilus influenzae type b; OPV: oral polio vaccine; MMR: measles, mumps \& rubella

cination services were below the acceptable level in those lots. According to the results, all lots (districts) in Elazı $\breve{g}$ were found to have acceptable level of vaccination services (Table 4).

In the study it was found out that $46.5 \%$ of children had "fully and timely vaccination". Associations between children's "fully and timely vaccination" status and some socio-demographic and family characteristics were examined with logistic regression modeling. Logistic regression modeling results showed that the estimated risk of inproper/inadequate vaccination had increased 0.28 times ( $95 \% \mathrm{CI}=0.13$ to 0.59 ) for having an unemployed mother; 1.78 times ( $95 \% \mathrm{CI}=1.23$ to 2.58 ) for having primary school graduate or less educated mothers; 1.05 times (95\% CI=1.01 to 1.10 ) for a unit increase in mother's age (in years); and 0.99 times ( $95 \% \mathrm{CI}=0.99$ to 0.99 ) for a unit increase in child's age (in days) (Table 5).

\section{DISCUSSION}

LQAS method is used both in Turkey and other countries in many different studies for assessment of vaccine coverage. ${ }^{11,13-19}$ The main reasons for common use of LQT in vaccine-related research is its ease in application, no need for a sampling frame record and/or large population size; ability to determine performance of individual sub-units in the population to identify those with "unacceptably low" coverage rates; and the possibility of chosing a range of different confidence intervals, and accuracy levels. LQAS may require a larger initial investment than administrative or cluster survey methods owing to larger sample sizes. On the other hand, it may be more cost effective in the long run by providing more detailed information and enabling better decision-making for the allocation of limited resources. ${ }^{16}$

TABLE 4: Assessment of immunization coverage with LQT in four selected provinces and the perfomances of lots (2010).

\begin{tabular}{|c|c|c|c|c|c|c|}
\hline \multirow[b]{2}{*}{ Province } & & \multicolumn{5}{|c|}{ Vaccine } \\
\hline & & BCG & DTaPHibIPV3 & OPV & Hepatitis B3 & MMR \\
\hline \multirow[t]{2}{*}{ Balıkesir } & Coverage (\%) & 99.4 & 98.9 & 98.9 & 98.8 & 98.7 \\
\hline & Unacceptable lot (\#) & - & 1 & - & 1 & 1 \\
\hline \multirow[t]{2}{*}{ Elazığ } & Coverage (\%) & 99.9 & 98.2 & 98.2 & 98.2 & 99.6 \\
\hline & Unacceptable lot (\#) & - & - & - & - & - \\
\hline \multirow[t]{2}{*}{ Giresun } & Coverage (\%) & 99.5 & 99.0 & 97.9 & 98.9 & 97.0 \\
\hline & Unacceptable lot (\#) & 1 & 1 & 1 & 1 & 1 \\
\hline \multirow[t]{2}{*}{ Samsun } & Coverage (\%) & 99.4 & 93.4 & 93.6 & 92.5 & 92.7 \\
\hline & Unacceptable lot (\#) & 1 & 2 & 1 & 1 & 1 \\
\hline
\end{tabular}

BCG: Bacille Calmette-Guérin; DTaPHibIPV3: Diphtheria, tetanus, pertussis, polio \& Haemophilus influenzae type b; OPV: oral polio vaccine; MMR: measles, mumps \& rubella. 


\begin{tabular}{|c|c|c|c|c|}
\hline Variables & $\%{ }^{*}$ & Beta & $\begin{array}{c}\text { Wald test } \\
\mathrm{p} \text { value }\end{array}$ & OR $(95 \% \mathrm{Cl})$ \\
\hline Constant coefficient & - & -1.555 & 0.121 & - \\
\hline \multicolumn{5}{|l|}{ Employment status of mother } \\
\hline Unemployed & 53.1 & 1.281 & 0.001 & $0.28(0.13-0.59)$ \\
\hline Employed & 59.0 & & & 1 \\
\hline \multicolumn{5}{|l|}{ Education level of mother } \\
\hline Primary school or below & 56.0 & -0.575 & 0.003 & $1.78(1.23-2.58)$ \\
\hline Secondary school or above & 49.1 & & & 1 \\
\hline \multicolumn{5}{|l|}{ Employment status of father } \\
\hline Unemployed & 61.8 & -0.315 & 0.270 & $1.37(0.78-2.42)$ \\
\hline Employed & 52.0 & & & 1 \\
\hline \multicolumn{5}{|l|}{ Education level of father } \\
\hline Primary school or below & 59.2 & -0.026 & 0.888 & $1.03(0.71-1.49)$ \\
\hline Secondary school or above & 48.5 & & & 1 \\
\hline \multicolumn{5}{|l|}{ Sex of the child } \\
\hline Female & 52.4 & 0.080 & 0.663 & $0.92(0.64-1.33)$ \\
\hline Male & 54.4 & & & 1 \\
\hline \multicolumn{5}{|l|}{ The number of siblings } \\
\hline No sibling & 49.5 & 0.565 & 0.110 & $1.76(0.95-3.25)$ \\
\hline One sibling & 51.6 & 0.168 & & $1.18(0.65-2.17)$ \\
\hline Two siblings & 58.4 & 0.229 & & $1.26(0.67-2.37)$ \\
\hline Three or more siblings & 63.2 & & & 1 \\
\hline Age of mother (years) & - & 0.051 & 0.021 & $1.05(1.01-1.10)$ \\
\hline Age of father (years) & - & 0.011 & 0.660 & $1.01(0.96-1 ., 06)$ \\
\hline Age of child (days) & - & -0.002 & 0.042 & $0.99(0.99-0.99)$ \\
\hline
\end{tabular}

${ }^{1}$ For each independent variable, odss ratio (OR) was calculated for children who had missed doses of any vaccine or who was vaccinated outside the specified times, according to the reference group, that is, being "fully and timely" vaccinated. Children, who completed one dose of BCG (at the end of the $8^{\text {th }}$ week), third dose of DaBTIPAHib3, OPV and Hepatitis B3 vaccines (at the end of the $24^{\text {th }}$ week) and one dose of MMR vaccine (at the end of the $52^{\text {th }}$ week) was accepted as the reference group in the model.

* Percentage of children who had missed doses of any vaccine or who was vaccinated outside the specified times

Several biostatisticians and epidemiologists have long been working on the validity of LQT to decide whether it is an easy and quick, yet, "errorprone" method. ${ }^{20}$ The LQT has been proved: 1) to have a high sensitivity (and of high negative predictive value at most settings), thus, to be good in detecting "low" performance if vaccine coverage rates are low, but 2) to have a lower specificity and positive predictive value, thus, underestimating units' performance in some cases where performance is sufficient. LQT has been found very efficient and useful in situations, where the population has an overall high coverage rate, yet, sub-units could have heterogeneous performance levels. Therefore, sample size calculations need to be done appropriately in order to reach valid estimates. ${ }^{21-24}$
In vaccination-related studies, the source of information was found to be strongly associated with the validity and reliability of the data on vaccination status, site of vaccination, and reasons for non-vaccination. ${ }^{25}$ Our study was based on self-reports, which could threaten the validity of our findings, leading to information bias. To minimize such an information bias, in particular recall bias, the "preferred" sources of information in the study were mothers of the children (between $85.4 \%$ and 90.3\%).

Besides estimation of coverage rates, the study aimed to examine various characteristics of children and their families, with an attempt to investigate how these factors might affect children's vaccination status. Educational attainment of both 
mothers and fathers were similar to national averages.

Transmission of vaccine-preventable diseases in 12-23 months old children may increase in presence of any young sibling or household member. In the study group, approximately two out of three children had at least one sibling and almost half of the families had five or more members except in Balıkesir (26.4\%). These findings suggested a potential for high transmission of any contagious disease among family members.

In almost the entire study group, the site for vaccination was mainly health center/family physician. This finding confirms that the health centers/family physicians are the mostly preferable sites for vaccination in Turkey. ${ }^{11,26,27}$ In both situations, it is a pleasant finding from the public health point of view, indicating that vaccination services are mainly received from primary health care settings. In addition, accessibility of vaccination services does not seem to be a hindering factor against immunization, given the finding that more than $50 \%$ of the children in each province reached vaccination services in less than 10 minutes. This percentage was $82 \%$ in Cakir's survey which was conducted three years ago. ${ }^{11}$ While interpreting these results it should not be underestimated that these "access times" were the declarations of the participants.

One of the major criteria for "quality" of vaccination services is the "presence of a vaccination card". Vaccination cards inform both the parents and the health personnel of the vaccination status of the children and timeliness and periodicity of vaccinations; alert for any interruption in services; and remind parents of the date of the "next" vaccination. The children were considered as immunized or not, based on their immunization cards. For those without an immunization card, self-report of the mother or any other responsible and reliable person in the family with respect to the immunization status of the child was considered. In the study group, $82.5-91.6 \%$ of participants showed their child's vaccination card to the interviewer, and according to self-reports of the children's caregiver, only $0.6-3.0 \%$ of the children had no vaccination card. It was found in earlier studies that only half of the mothers' kept and showed vaccination cards of their children. ${ }^{11,25}$ Health personnel working in the field should emphasize the importance of having and keeping a vaccination card during their training and consultation services in the field and should motivate parents in this respect.

This study pointed out the importance of emphasizing vaccination date in educating parents or providing consultation on vaccine-related issues. Based on the nationally recommended schedule, "timeliness of vaccination" ranged in the study population between $47.4 \%$ and $78.4 \%$. These percentages were found to be lower than Cakir's study (63.0\% and $87.0 \%)$, which was conducted in the urban district of Ankara. ${ }^{11}$ This calculation was based on the data from those with a vaccination card only. Timeliness of vaccination could not be evaluated for those without a vaccination card and those who could not show their card at the time of the interview, but would have similar, prevalence rates.

Although minimal differences was found between the means of OPV, Hepatitis B3 and DTaPHibIPV3 vaccines application times in the study, there is no statistically significantly difference between groups. It had not been investigated in this study but possible reasons for this difference may be the lack of some vaccines in the health facility for the moment or family/health care personnel may be request to put a time period between the injections or vaccines applications to avoid from vaccine's side effects (e.g. fever).

The study also investigated reasons for nonvaccination. The above-mentioned reasons correspond well to previous findings in local and national studies, and seemed to be related to educational constraints, rather than problems of availability, accessibility or acceptability of services. ${ }^{11,14,26,28}$ Reasons reported in the study did not vary significantly by the type of the vaccine and a significant proportion of parents did not report a specific reason for non-vaccination, limiting the evidence to offer effective interventions. Future qualitative research (focus group discussions, in- 
depth interviews, etc.) on reasons for non-vaccination may be important and effective, in this respect. Reasons associated with vaccination failure may vary in each nation, region, and/or time period, therefore it is important to evaluate coverage rates periodically and to determine reasons of non-vaccination (if any) to develop interventions, customized individually with respect to specific status and needs, with an ultimate goal of maximizing childhood vaccines' coverage rates nation wide.

In this study, we identified within-city differences in vaccination coverage as well as a citywide estimate using LQAS. The first aim of the study was to determine vaccine coverage rates in the selected provinces. It was found out that $77.0 \%$ of the $15-26$ months old children received the full schedule of vaccination against seven diseases. ${ }^{29}$ The results of a study conducted in İstanbul with LQT, revealed that $75.6 \%$ of the children aged $12-23$ months were fully vaccinated. ${ }^{13}$ Prevalance rate for full immunization in the selected provinces (88.6-98.1\%) were found to be close to the national average. ${ }^{30}$ Despite small variations, coverage rate in the area is satisfactory for almost all vaccines (Table 4). The vaccination coverage rates in infants with systematic vaccination in 2001 were $82 \%$ for BCG, $83 \%$ for DTP3, 83\% for polio 3, 72\% for Hepatitis B3, and $84 \%$ for measles which increased to $96 \%$ for BCG and DTaPHibIPV3, 92\% for Hepatitis B3, and 97\% for measles, in 2008 . $^{28,30,31}$ These rates point out to the local health personnel's success in vaccination services and also the positive effects of the "Health Transformation Program" administered by the Ministry of Health of Turkey since 2002.

One of the limitations of the method used in the study is that a specific estimate for each sub-unit cannot be evaluated, instead, they are classified as having 'acceptable' or 'unacceptable' vaccination coverage based on upper and lower cut-offs defined for the specific survey. ${ }^{32}$ Two of the "lots" in Balıkesir, one of the "lots" in Giresun, and two of the "lots" in Samsun had coverage rates of less than 75\%. In another study conducted in İstanbul, despite the low threshold levels (65\%), the quality of the vaccination services was below the acceptable level in 24 lots. ${ }^{13}$ The levels of vaccina- tion coverage are above $75 \%$ in most districts of selected provinces; however, these results should not be interpreted as vaccination services to be complete. There are unvaccinated children in the major part of the "lots" for almost all of vaccines.

The association between children's "fully and timely vaccination" status and some socio-demographic and family characteristics were examined with logistic regression modeling. As confirming the expectation and similar to the previous studies; immunization status improves with the age of child and the employment status, and also with the educational level and the age of mother. ${ }^{11,33}$ In the study, employment status of the mothers found to be negatively associated with completeness of vaccination of their children, controlling for employment status of the father, education level of the mother and father, sex and age of the child, number of the siblings and ages of the mother and the father. Detailed investigation of the underlying reason for this is beyond the scope of this study, yet, needs to be further investigated in future qualitative studies.

\section{CONCLUSION AND RECOMMANDATION}

The percentages of fully immunized children were well above of the coverage level of national average, and were in parallel to intense labor and efforts in these provinces. Interventions are required for keeping the existing standard in services.

Unvaccinated children still continue to exist. Enhancing the level of care of vaccination services will be appropriate for the lots where number of unvaccinated children is two or more. In order to expand the immunization services in this group, interventions should be developed by determining the characteristics of these unvaccinated children. Childhood immunization services are one of the most cost-effective health services. Vaccination does not only protect the health of children, but also plays an important role in protecting other children and adults living in the same environment against infectious diseases. Accessibility and acceptability of services are also important in immunization.

Timely vaccination should be at the forefront for countries such as Turkey, which had an impor- 
tant progress on the fight against vaccine-preventable diseases. Implementation of the vaccination schedule is not enough in prior to graduation and in-service training programs of health personnel, it is also necessary to emphasize the implementation of "on time" of vaccination and families should be trained and motivated to have their children's vaccines both as "fully" and "on time".

Children, who can not access or who do not attend primary health care centers should also be considered in vaccination services. This topic should be further investigated in future case-based surveillance and/or coverage studies; and administrative methods should be backed up by household surveys to strengthen vaccination monitoring in regions.
Lastly, LQT, is still an appealing technique for rapid evaluation of the extent of a variety of local health concerns and is very efficient in determining performance of individual subunits (districts, health centers etc.) in a given service area. Thus, training of local health personnel on use of LQT could expedite response to local health problems and would even motivate them in conducting their own surveys tailored to their professional interests.

\section{Acknowledgement}

For their contributions to this study we would like to extend thanks to; Prof.Dr. Recep Akda $\breve{g}$ the Minister of Health, Prof.Dr. Nihat Tosun the Undersecretary of the Minister of Health, Prof.Dr. Banu Çakır, Dr. Ercan Bal, Dr. Aslıhan Coşkun, Dr. Zekiye Çelebi and Dr. Feray Karman.

\section{REFERENCES}

1. The European Health Report 2009: Health and Health Systems. Mitigating the burden of communicable diseases. Copenhagen: World Health Organization; 2009. p.59-63.

2. UNICEF, WHO. Turkey. Immunization Summary: A Statistical Reference Containing Data Through 2008. United Nations International Children's Emergency Fund and World Health Organization; 2010. p.179-80.

3. Roush S, Bennett S, Hughes $\mathrm{H}$, Wharton M. Enhancing surveillance. In: Wharton $M$, Hughes $\mathrm{H}$, Reilly M, eds. Manual for the Surveillance of Vaccine Preventable Diseases. Centers for Disease Control and Prevention, Atlanta, GA: CDCP; 1997. p.1-7.

4. WHO/IVB. WHO Vaccine-Preventable Diseases Monitoring System, 2006 Global Summary. Global and regional summaries. Geneva: Expanded Programme on Immunization of the Department of Immunization, Vaccines and Biologicals, World Health Organization; 2006. p.10-26.

5. WHO, UNICEF. GIVS: Global Immunization Vision and Strategy 2006-2015. Strategic framework for 2006-2015. WHO Department of Immunization, Vaccines and Biologicals and UNICEF Programme Division, Health Section. Geneva: World Health Organization; 2005. p.17-31.

6. WHO/IVB. Immunization Coverage Cluster Survey-Reference Manual. Basic principles of sampling for surveys. Geneva: The Department of Immunization, Vaccines and Biologicals. Geneva: World Health Organization; 2005. p.35-50.
7. WHO. Monitoring Immunization Services Using The Lot Quality Technique. Plan, prepare and conduct the survey. Geneva: WHO Global Programme for Vaccines and Immunization, Vaccine Research and Development, World Health Organization; 1996. p.5-42.

8. Valadez JJ. Assessing Child Survival Programs in Developing Countries-Testing Lot Quality Assurance Sampling. Boston: Cambridge, MA, Harvard University Press; 1991. p.247.

9. Robertson SE, Valadez JJ. Global review of health care surveys using lot quality assurance sampling (LQAS), 1984-2004. Soc Sci Med 2006;63(6):1648-60

10. Sağlık Bakanlı̆ı Temel Sağlık Hizmetleri Genel Müdürlüğü.13.03.2009 tarihli, 7941 Sayılı Genişletilmiş Bağışıklama Programı Genelgesi.

11. Cakir B, Uner S, Temel F, Akin L. Lot quality survey: an appealing method for rapid evaluation of vaccine coverage in developing countries-experience in Turkey. BMC Public Health 2008:8:240

12. [Aile Hekimliği Uygulamasında Performans Hesaplama Yöntemi]. Sürüm 2.1, TC Sağlık Bakanlığı Bilgi İşlem Daire Başkanlığı Performance Deduction Formulas-Vaccination Success Rate; 2007. p.17-9.

13. Alkoy S, Ulugtekin N, Dogru AO. Monitoring vaccination coverage in Istanbul using the lot quality assurance sampling and geographic information system. J Int Med Res 2007;35(2): $242-52$.
14. Torun SD, Bakirci N. Vaccination coverage and reasons for non-vaccination in a district of Istanbul. BMC Public Health 2006;6: 125.

15. Validation of elimination of neonatal tetanus in Turkey by lot quality assurance cluster sampling. Wkly Epidemiol Rec 2009;84(17):1416

16. Alberti KP, Guthmann JP, Fermon F, Nargaye KD, Grais RF. Use of Lot Quality Assurance Sampling (LQAS) to estimate vaccination coverage helps guide future vaccination efforts. Trans R Soc Trop Med Hyg 2008;102(3):2514.

17. Tapare VS, Borle PS. Assessment of vaccination performance by lot quality technique in an urban community of miraj. Indian J Community Med 2006;31(3):181-2.

18. Luman ET, Worku A, Berhane $Y$, Martin R, Cairns $L$. Comparison of two survey methodologies to assess vaccination coverage. Int $\mathrm{J}$ Epidemiol 2007;36(3):633-41.

19. Punith K, Lalitha K, Suman G, Pradeep BS, Jayanth Kumar K. Evaluation of primary immunization coverage of infants under universal immunization programme in an urban area of Bangalore City using cluster sampling and lot quality qssurance sampling techniques. Indian $\mathrm{J}$ Community Med 2008;33(3):151-5.

20. Sandiford P. Lot quality assurance sampling for monitoring immunization programmes: cost-efficient or quick and dirty? Health Policy Plan 1993;8(3):217-23. 
21. Luman ET, Worku A, Berhane $Y$, Martin R, Cairns L. Comparison of two survey methodologies to assess vaccination coverage. Int $\mathrm{J}$ Epidemiol 2007;36(3):633-41.

22. Sivasankaran $S$, Manickam $P$, Ramakrishnan R, Hutin Y, Gupte MD; Centers for Disease Control and Prevention (CDC). Estimation of measles vaccination coverage using the Lot Quality Assurance Sampling (LQAS) method--Tamilnadu, India, 2002-2003. MMWR Morb Mortal Wkly Rep 2006; 55(Suppl 1):16-9.

23. Singh J, Jain DC, Sharma RS, Verghese T. Evaluation of immunization coverage by lot quality assurance sampling compared with 30 cluster sampling in a primary health centre in India. Bull World Health Organ 1996;74(3): 269-74.

24. Harris DR, Lemeshow S. Evaluation of the EPI survey methodology for estimating relative risk. World Health Stat Q 1991;44(3):10714.
25. Ramakrishnan R, Rao TV, Sundaramoorthy L, Joshua V. Magnitude of recall bias in the estimation of immunization coverage and its determinants. Indian Pediatr 1999;36(9):881-5.

26. Mutlu Ş, Öztüfekçi H, Bardakçı N. [Examination of the immunization status of 13-24 month children with lot quality tecnique in Izmir]. STED 2002;11(10):380-2.

27. Canbaz S, Pekşen Y, Sünter AT. [Comparison of information obtained from mothers with health center records about immunization]. Journal of Cumhuriyet University School of Nursing 2001;5(1):48-53.

28. Ayçiçek A. [Immunization rates of 2-23 months children on the rural area of Şanlıurfa]. Turkish Pediatric Journal 2004;47(3):183-8.

29. Hacettepe University Institute of Population Studies. Türkiye Nüfus ve Sağılk Araştırması 2008. Ankara: Republic of Turkey Ministry of Health, Republic of Turkey Prime Ministry Undersecretary of State Planning Organization; 2009. p.345.
30. Ministry of Health of Turkey. [Prevention of diseases and protection of health]. Mollahaliloğlu S, Başara BB, Eryılmaz Z, editörler. Sağlık İstatistikleri Yıllığı 2009. Ankara: The Ministry of Health of Turkey, Refik Saydam Hygiene Center Presidency, School of Public Health; 2011.p.37-51

31. [Temel Sağlık Hizmetleri Genel Müdürlüğü 2001 Yıllığı]. Basic Health Services: Tables and Figures. Ankara: TC Sağlık Bakanlığı; 2002. p.73.

32. Hoshaw-Woodard S. Brief description of lot quality assurance sampling. Description and Comparison of the Methods of Cluster Sampling and Lot Quality Assurance Sampling to Assess Immunization Coverage. WHO/V\&B/ 01.26. Geneva: Department of Vaccines and Biologicals, World Health Organization; 2001. p.5-6.

33. Şimşek Z, İnakçı IH, Koruk I, Shermatov K. [Vaccination status in children aged 12-23 months and predictors in Şanlıurfa]. Turkiye Klinikleri J Pediatr 2010;19(1):20-9. 